\title{
ERRATUM
}

\section{Developing Leadership and Employee Health Through the Arts}

\section{Improving Leader-Employee Relationships}

\author{
Julia Romanowska, Anna Nyberg and Töres Theorell
}

(C) Springer International Publishing Switzerland 2016

J. Romanowska et al., Developing Leadership and Employee Health Through the Arts, DOI 10.1007/978-3-319-41969-5

DOI 10.1007/978-3-319-41969-5_5

\section{1) Order of author names:}

The order of the author names as mentioned in the front matter and cover of the book has been changed due to its incorrectness to the following order: Julia Romanowska, Anna Nyberg, and Töres Theorell.

2) Inclusion of author names:

(i) Chapter opening pages:

Corresponding chapter author names have been included in the opening page of each chapter:

Page 1: Töres Theorell

Page 55: Anna Nyberg

Page 99: Julia Romanowska

Page 177: Julia Romanowska, Anna Nyberg and Töres Theorell

The updated original online version for this book can be found at DOI 10.1007/978-3-319-41969-5 
(ii) Table of Contents:

Corresponding chapter author names have been included for each chapter in the Table of Contents:

Chapter 1:

Arts, Health and Job Stress

Töres Theorell

Chapter 2:

Destructive Leadership - Processes and Consequences

Anna Nyberg

Chapter 3:

The Transformative Power of Aesthemetics

Julia Romanowska

Chapter 4:

Concluding Remarks

Julia Romanowska, Anna Nyberg and Töres Theorell

\section{3) Missing references:}

The reference to the authors who have participated in the individual chapters was not mentioned in the previous version of this book, which has now been included.

The references are:

Chapter 1: Theorell, T. (2016). Arts, health and job stress. In J. Romanowska, A. Nyberg, \& T. Theorell (Eds.), Developing leadership and employee health through the arts (pp. 1-53). Cham: Springer International Publishing.

Chapter 2: Nyberg, A. (2016). Destructive leadership-processes and consequences. In J. Romanowska, A. Nyberg, \& T. Theorell (Eds.), Developing leadership and employee health through the arts (pp. 55-98). Cham: Springer International Publishing.

Chapter 3: Romanowska, J. (2016). The transformative power of aesthemetics. In J. Romanowska, A. Nyberg, \& T. Theorell (Eds.), Developing leadership and employee health through the arts (pp. 99-175). Cham: Springer International Publishing. 


\section{4) Figure corrections:}

\section{Chapter 1:}

Page 5, in the caption below the figure, the phrase "(rollover to enlarge)" has been removed.

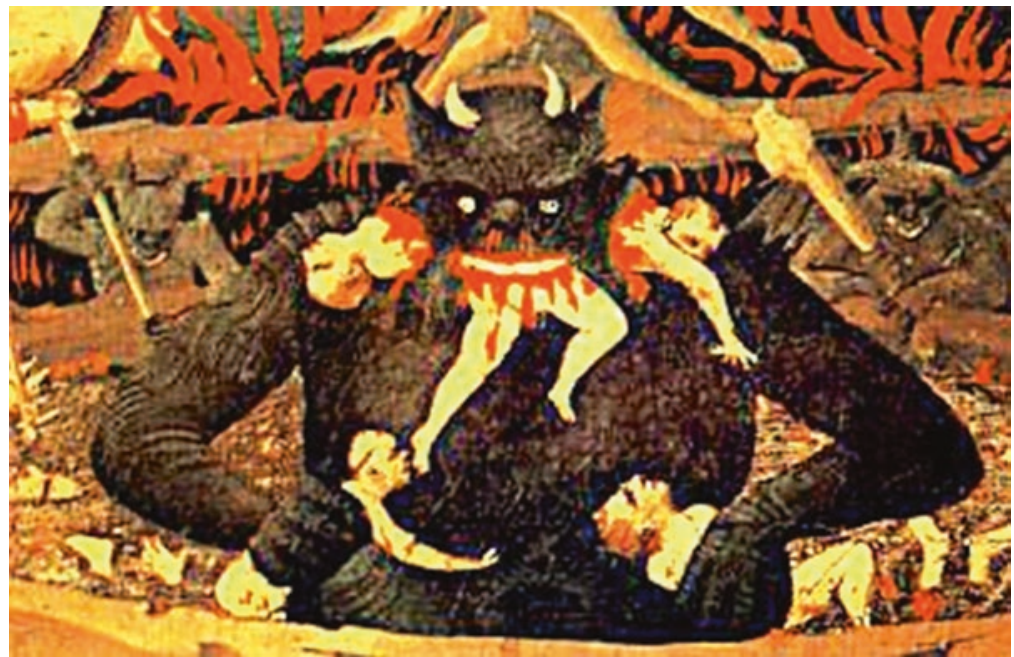

The Last Judgement: Hell, detail

(Fra Angelico, 1431)

\section{Chapter 2:}

Page 63, Fig. 1 and its caption has been replaced with a new version.

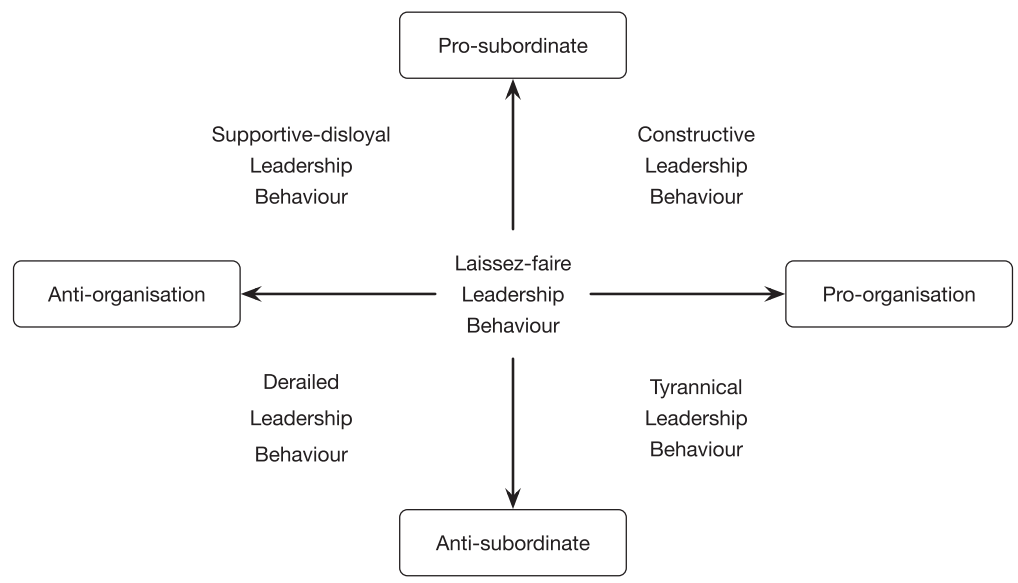

Fig. 1 A model of destructive leadership as defined in Aasland et al. (2010) 
Page 80, Fig. 3 has been replaced with a new version.

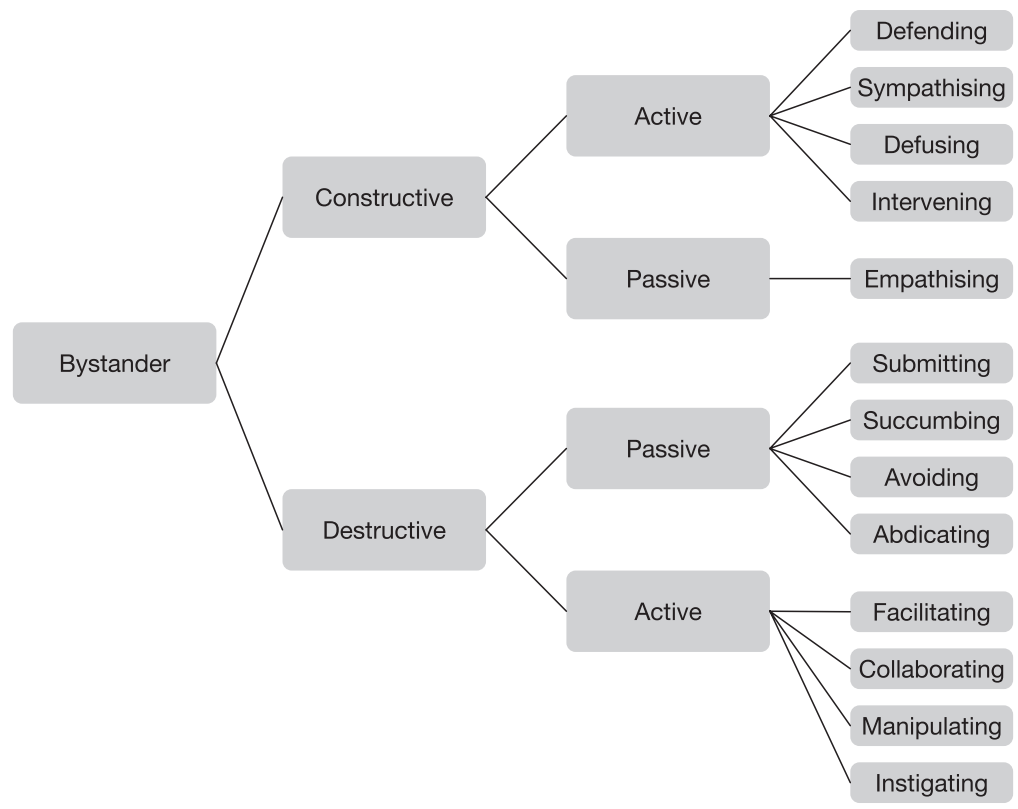

Fig. 3 The thirteen potential bystander roles presented by Paull et al. (2012) 


\section{Chapter 3:}

Page 114, the credit line has been included in the caption of Picture 2.

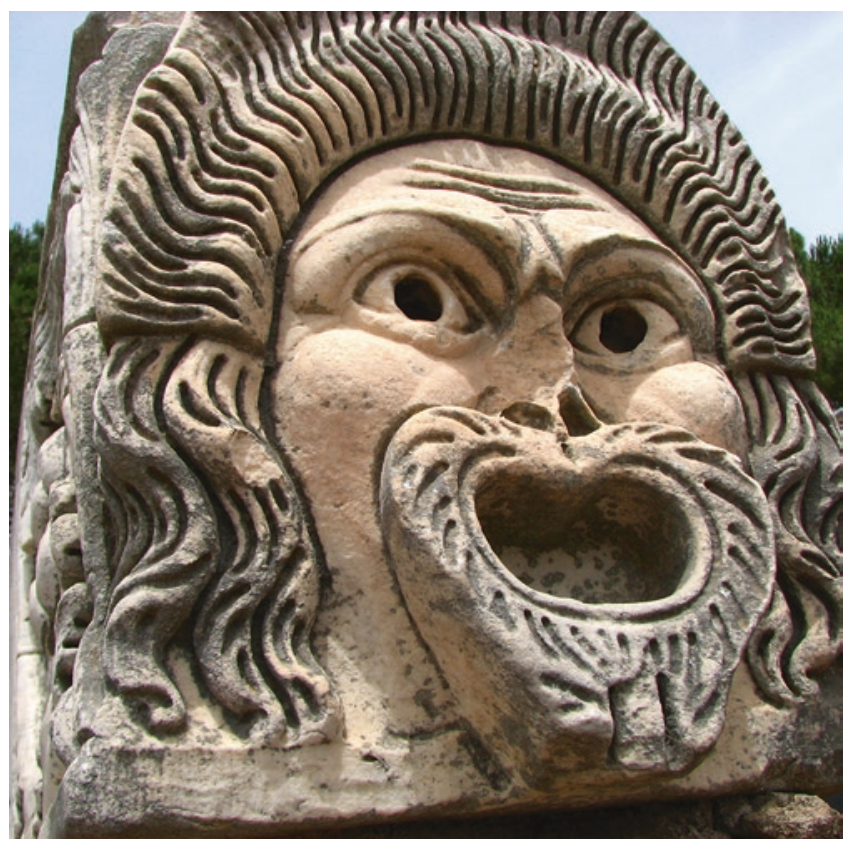

Picture 2 Theatrical mask, part of the architectural decoration of the theatre (regio II, insula VII). Ostia Antica, Rome, Italy (Credit: Patrick Denker/ CC-BY-SA-3.0) 